\title{
Comparison of two biological internal fixation techniques in the treatment of adult femur shaft fractures (plate-screws and locked intramedullary nail)
}

\author{
Erişkin femur cisim kırıklarında biyolojik tespit için kullanılan iki tekniğin \\ karşılaştırılması (Plak-vida ve kilitli intramedüller çivi)
}

\author{
Ertuğrul KÖSEOĞLU, ${ }^{1}$ Kemal DURAK, ${ }^{2}$ Muhammed Sadık BİLGEN, ${ }^{2}$ \\ Abdullah KÜÇÜKALP, ${ }^{2}$ Sarp BAYYURT ${ }^{2}$
}

\section{BACKGROUND}

We aimed to compare two (plate-screws and locked intramedullary nail) biological internal fixation techniques in the treatment of adult femur shaft fractures.

\section{METHODS}

Group I included 28 patients operated with biological internal fixation with plate and screws. Group II consisted of 31 patients operated with locked intramedullary nailing technique. During the follow-up period in Group I, 1 patient died and 3 patients dropped out of the study, so the results of 24 patients were evaluated. During the follow-up period in Group II, 2 patients died and 3 patients dropped out of the study, so the results of 26 patients were evaluated in this group.

\section{RESULTS}

Age, sex, injury mechanism, fracture type, time to operation, duration of operation, amount of bleeding, fluoroscopy usage time, early and late complications, duration of hospitalization, fracture union time, and functional results of all patients were comparatively evaluated.

\section{CONCLUSION}

According to our results, no superiority of either technique was demonstrated with respect to fracture union time, complication rate and functional results. Biological internal fixation with plate and screws is an alternative technique to locked intramedullary nailing in patients with multi-trauma or compromised pulmonary or cardiac function, or in complex comminuted or segmented diaphyseal or metaphyseal fractures.

Key Words: Biological internal fixation; femur shaft fracture; plate and screws; locked intramedullary nail.

\section{AMAÇ}

Bu çalışmada, erişkin femur cisim kırıklarında biyolojik tespit için kullanılan iki teknik (plak-vida ve kilitli intramedüller çivi) karşılaştırıldı.

\section{GEREÇ VE YÖNTEM}

Plak-vida ile biyolojik içten tespit yapılan 28 hasta grup I, kilitli intramedüller çivi kullanılan 31 hasta grup II olarak ayrıldı. Grup I'den 1 hastanın ölmesi ve 3 hastanın da takip sırasında kontrollere gelmemesi nedeni ile 24 hasta çalışmaya dahil edildi. Grup II'de ise 2 hastanın ölmesi ve 3 hastanın da takipleri sırasında kontrollere gelmemesi nedeni ile 26 hasta çalışmaya dahil edildi.

\section{BULGULAR}

Grup I ve grup II'deki olguların yaş ve cinsiyetleri, yaralanma nedenleri, kırık tipleri, ameliyata alınma zamanları ve ameliyat süreleri, kanama miktarları, floroskopi kullanım ve hastanede yatış süreleri, erken ve geç dönem komplikasyonları, kaynama zamanı ve fonksiyonel sonuçları karşılaştırılmalı olarak değerlendirildi.

\section{SONUÇ}

Sonuçta, kullanılan her iki yöntemin, kaynama süreleri, komplikasyon oranları ve fonksiyonel sonuçlar açısından birbirine üstünlükleri olmadığı; plak ile biyolojik tespitin, özellikle çoklu yaralanmalı, pulmoner ve kardiyovasküler sistemi risk altında olan hastalarda ve parçalı, segmenter cisim ya da metafiz kırıklarında kilitli intramedüller çivilere tercih edilebilecek alternatif bir yöntem olduğu görüşüne varıldı.

Anahtar Sözcükler: Biyolojik içten tespit; femur cisim kırı̆̆ı; plak ve vida; kilitli intramedüller çivi.

\footnotetext{
${ }^{1}$ Department of Orthopaedics and Traumatology, Kütahya State Hospital, Kütahya; ${ }^{2}$ Department of Orthopaedics and Traumatology, Uludag University Faculty of Medicine, Bursa, Turkey.
} Anabilim Dal, Bursa. 
Femur shaft fractures are among the most common fractures and occur as a result of high-energy trauma. Without appropriate treatment, they carry high morbidity and mortality rates.

There are many methods for the treatment of femur shaft fractures. The surgeon must be aware of the indications, advantages and disadvantages of each treatment option and decide the appropriate treatment method for each patient individually. Fracture type, location, presence of comminution or not, patient age, and lifestyle expectation are important factors when selecting the treatment method.

Closed reduction and cast immobilization, skeletal traction, external fixation, and internal fixation are the possible treatment choices. Because of the high complication rate of conservative treatment, surgical procedures are the first options for treatment of femur shaft fractures. ${ }^{[1,2]}$

The initial mechanical concept of osteosynthesis of long bone fractures was introduced by the Arbeitsgemeinschaft für osteosynthesefragen / Association for the Study of Internal Fixation (AO/ASIF) group and aimed at perfect anatomic reduction and stable fixation. ${ }^{[3]}$ Primary bone healing without external callus formation was the target. However, in comminuted fractures, anatomic reduction requires extensive soft tissue stripping and subsequent damage to the blood supply at the fracture site. ${ }^{[4-6]}$ After observing the better results with closed intramedullary nailing (IMN) in comminuted fractures, priority changed from a mechanical to biological basis. ${ }^{[7-10]}$ With biological aspects, attention has shifted from absolute anatomic reduction and stability toward the preservation of tissue vascularity while obtaining anatomic alignment and relative stability. ${ }^{[6,11]}$ Biological internal fixation avoids the need for precise reduction, especially of the intermediate fragments, and has the advantage of
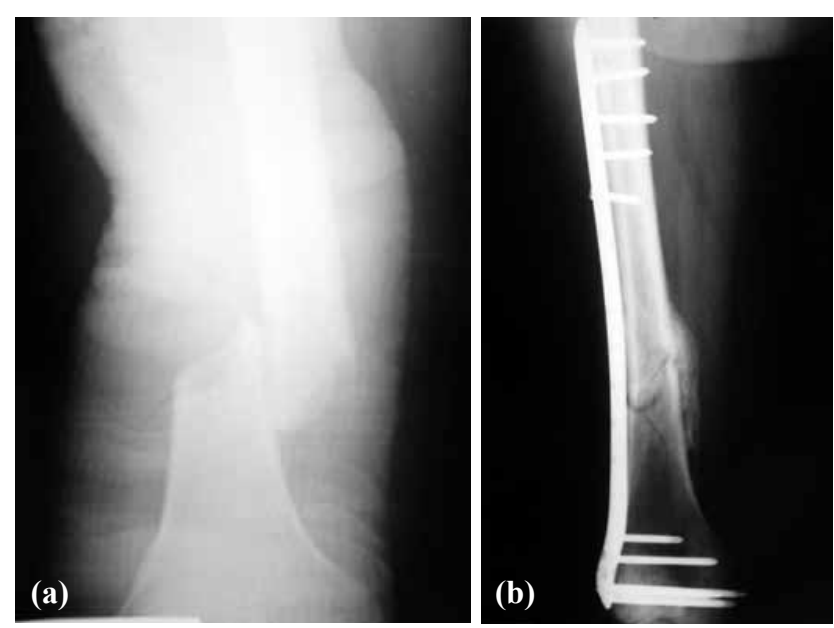

Fig. 1. Case from Group I treated with LISS plate: (a) preoperative radiograph and (b) radiograph after union. indirect reduction. ${ }^{[6]}$ For this purpose, external fixators, plate and screws, and intramedullary nails can be used. In biological fixation, these plates or nails act as a "splint" to maintain fracture alignment without absolute stability. ${ }^{[2,12-14]}$

In comminuted fractures, the plate initially is the only load carrier of the construct. However, indirect reduction and relative stability of the fracture result in secondary callus formation. As the fracture union completes, load is gradually transferred to bone. ${ }^{[15-17]}$

In this study, we evaluate the clinical and radiological results of adult femoral shaft fractures comparatively as treated with either plate-screws or IMN as a biological fixation technique.

\section{MATERIALS AND METHODS}

Fifty-nine adult patients seen in Uludag University, Faculty of Medicine, Department of Orthopedics and Traumatology between November 2003 and May 2007 were operated due to femur shaft fractures with biological internal fixation with plate and screws or with locked IMN.

Twenty-eight patients operated with biological internal fixation with plate and screws were included in Group I, while 31 patients operated with locked IMN technique constituted Group II. During the followup period in Group I, 1 patient died and 3 patients dropped out of the study, so the results of 24 patients were evaluated. During the follow-up period in Group II, 2 patients died and 3 patients dropped out of the study, so the results of 26 patients were evaluated in this group.

Demographic details of the patients, mechanism of injury, associated injuries, type of fracture, open or closed injury, time to union, malunion, nonunion, and local and systemic complications were recorded.

The fractures were classified according to the AO system. ${ }^{[18]}$ Gustilo-Anderson open fracture classification was used for open fractures. ${ }^{[19]}$

In Group I, all patients underwent surgery on standard tables in the supine position. Two separate $5 \mathrm{~cm}$ incisions were made above and below the fracture site. According to the fracture type, less invasive stabilization system (LISS) plate, locking compression plate (LCP), dynamic compression plate (DCP), or anatomic plate were slid below the muscle tissue extraperiosteally across the fracture site from mini incisions above and below the fracture line. All fractures were reduced with closed techniques described by Krettek et al. ${ }^{[20]}$ Frontal alignment was assessed using the cable technique and rotational alignment was determined by assessing the shape of the lesser trochanter under fluoroscopy as described by Krettek et al. ${ }^{[20]}$ Leg length disparity was avoided by comparison with the unin- 
jured leg. At least 3 screws were used proximally and distally for fixation of the plate (Fig. 1a, 1b).

In Group II, patients were placed in the supine position on standard tables. An incision centered over the great trochanter was made and an entry into the proximal femoral canal was made through the piriform fossa. Appropriate nail length and size were determined intraoperatively under fluoroscopic control of the other femur. Antegrade nail insertion was used. In a few patients, the nails could not be inserted with closed technique. In these patients, the fracture was reduced with an approximately $4 \mathrm{~cm}$ incision over the fracture line without stripping soft tissue support of the fractured fragments. Static or dynamic locking screws were applied proximally and distally according to the fracture type. Proximal screws were applied with insertion guide while distal screws were applied with free hand technique (Fig. 2a, 2b, 2c).

Duration of operation, fluoroscopy time and blood loss were determined in both groups.

Isometric exercises for quadriceps were started at the postoperative first day, and patients were mobilized with crutches on the postoperative second day. Toe-touch weight bearing was encouraged for 6 weeks followed by partial to full weight-bearing depending on the progress of fracture healing. Monthly clinical and radiological follow-up was performed in the first 6 months and every 2 months thereafter.

Union was defined as the absence of pain and instability at the fracture site and presence of radiologi- cal consolidation of the fracture site.

SPSS 13.0 for Windows Statistical Analysis Package was used in the analysis of the data set. Categorical variables were given as number and percentile with frequency tables; continuous variables were given as mean and standard deviation and minimum and maximum values. In the analysis of categorical variables, Pearson's chi-square test and Fisher's exact chi-square test were used. In the analysis of continuous variables, one sample Kolmogorov-Smirnov test was used for analyzing the normal distribution. In comparison of variables with normal distribution, two sample $\mathrm{T}$ test was used, while Mann-Whitney U test was used for variables that were not normally distributed. A p value of 0.05 was considered significant.

\section{RESULTS}

The study population comprised 24 patients $(13$ male, 11 female) in Group I and 26 (20 male, 6 female) patients in Group II. The mean age of Group I was 48.8 (range: $21-73$ ) years and of Group II was 35.6 (range: 18-72) years. There were statistical differences between the groups $(\mathrm{p}<0.05)$.

High-energy traumas like traffic accidents were the leading cause of injury in both groups (13 patients in Group I and 20 patients in Group II). There were 4 bilateral femur fractures in Group II.

When the fractures were classified according to the AO system, comminuted fractures (AO type B and $\mathrm{C}$ ) were statistically higher in Group I $(\mathrm{p}<0.05)$ (Table 1$)$.
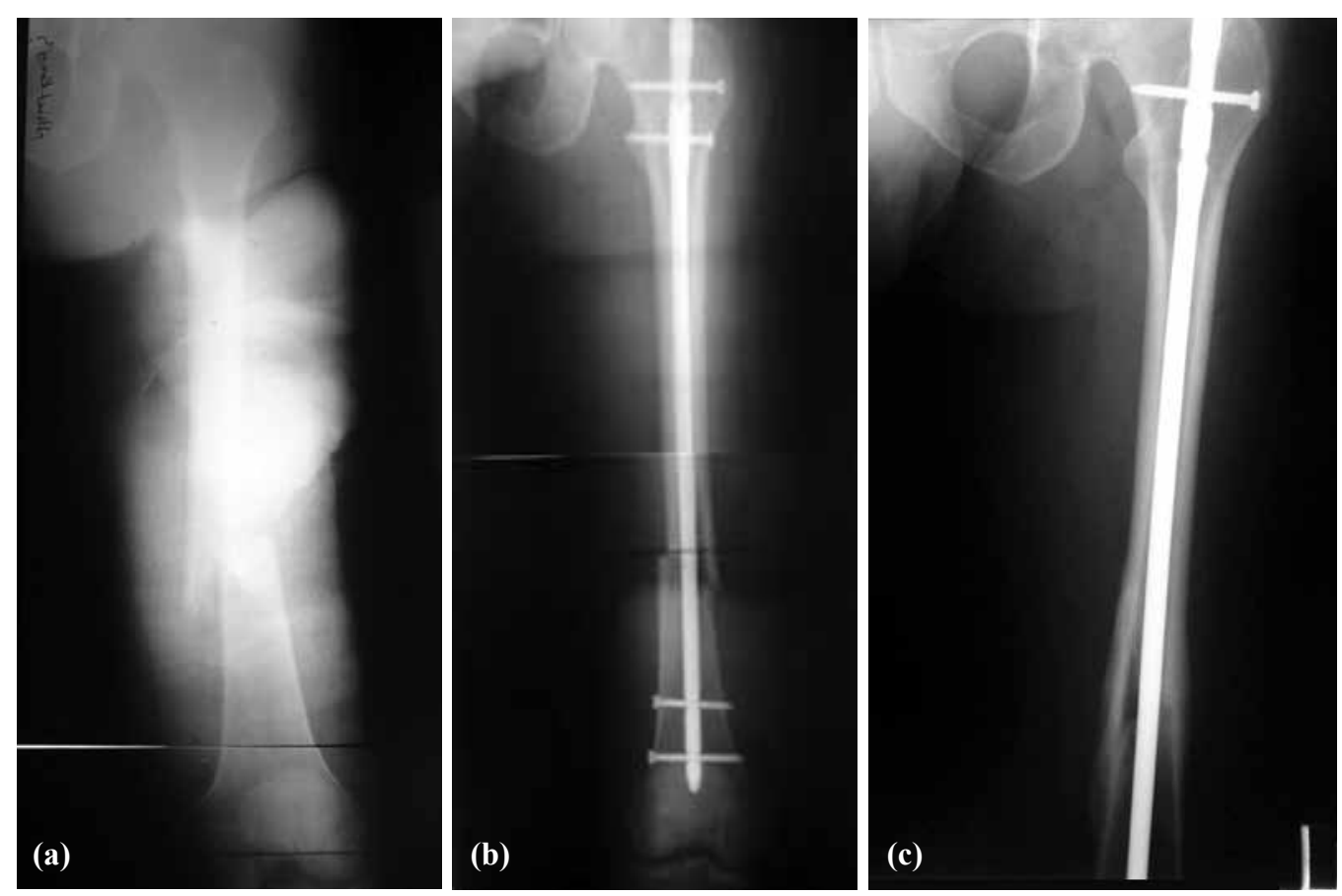

Fig. 2. Case from Group II treated with locked intramedullary nailing: (a) preoperative radiograph, (b) postoperative radiograph and (c) radiograph after union. 
Table 1. Fracture types according to AO/ASIF classification

\begin{tabular}{|c|c|c|c|c|c|c|}
\hline \multicolumn{3}{|c|}{$\mathrm{AO} / \mathrm{ASIF}$ classification of patients } & \multicolumn{2}{|c|}{ Group I } & \multicolumn{2}{|c|}{ Group II } \\
\hline & & & $\mathrm{n}$ & $\%$ & $\mathrm{n}$ & $\%$ \\
\hline \multirow{9}{*}{$\begin{array}{l}\mathrm{AO} \\
(n=32)\end{array}$} & A & A1 & 1 & 4 & 1 & 3 \\
\hline & & $\mathrm{A} 2$ & 2 & 8 & 3 & 10 \\
\hline & & A3 & 3 & 13 & 15 & 50 \\
\hline & B & B1 & 2 & 8 & 5 & 18 \\
\hline & & B2 & 1 & 4 & 1 & 3 \\
\hline & & B3 & 2 & 8 & 1 & 3 \\
\hline & $\mathrm{C}$ & $\mathrm{C} 1$ & 2 & 8 & 2 & 6 \\
\hline & & $\mathrm{C} 2$ & 2 & 8 & 2 & 6 \\
\hline & & C3 & 9 & 38 & - & - \\
\hline
\end{tabular}

Additional systemic injuries were present in 7 cases in Group I and 3 cases in Group II. In both groups, tibia fractures were the most common fractures accompanying the femur fractures ( 3 in Group I and 5 in Group II).

According to Gustilo-Anderson open fracture classification, 2 cases were type 2 and 1 case was type 3B open fracture in Group I, while 2 cases were type 2 and 1 case was type 1 open fracture in Group II.

The median time between injury and definitive surgery was 5.4 days in Group I and 5.3 days in Group II $(p>0.05)$. The mean duration of operation in Group I was $121.8 \pm 50.4 \mathrm{~min}$ and in Group II was $122.0 \pm 40.1$ min. There were no statistical differences between groups ( $>00.05$ ). Average blood loss was 239.5 (100$500) \mathrm{ml}$ in Group I and 205.0 (100-500) $\mathrm{ml}$ in Group II ( $\mathrm{p}>0.05)$. Average fluoroscopy usage time was 4.41 (3-8) $\mathrm{min}$ in Group I and 4.43 (3-7) $\mathrm{min}$ in Group II $(\mathrm{p}>0.05)$.

In Group I, of the 24 fractures, 8 were treated with LISS plate, 4 with LCP, 11 with DCP, and 1 with anatomic plate. In Group II, of the 30 fractures, 24 were treated with unreamed intramedullary femoral nail, 5 with reamed intramedullary femoral nail and 1 with miss-a-nail.

In Group II, static locking was chosen in 23 fractures and dynamic locking in 7 fractures. Open reduction was performed in 10 cases in Group II when the closed reduction could not be achieved.

Bone grafting was not used in primary surgery in either group.

The average hospital stay was 16.8 (7-25) days in Group I and 14.2 (5-30) days in Group II ( $p>0.05)$. Patients were followed for a mean of 19.7 months in Group I and 20.9 months in Group II ( $p>0.05)$. The mean time to union was $5(3.5-10)$ months in Group I and 4.6 (3-6) months in Group II ( $\mathrm{p}>0.05)$.

In Group I, 1 superficial infection and 1 deep infec- tion were detected. The case with deep infection was debrided twice and bone union was achieved at the 9th month. There were 2 delayed union cases in Group I. One of these patients had admitted with implant failure at the 5th month of surgery, while the other patient had admitted at the 15th month with nonunion. This case was an open fracture and the patient was sent to our hospital with wound infection. This patient had not presented for routine follow-up after discharge. Both patients underwent surgery with new plate-screws fixation and additional autografting. Union was achieved at the 5th month in both patients.

In 1 patient in Group I, a $2 \mathrm{~cm}$ limb length disparity was determined. This patient had a minor fall at the 4th month of surgery. On X-ray, there was a $15^{\circ}$ varus angulation of the plate. The patient was reoperated and the plate was removed. At the time of operation, there was adequate callus formation at the fracture site. Treatment was then completed at the patient's own initiative.

In Group II, there was 1 superficial infection. Three patients had $5^{\circ}$ varus angulation and 3 patients had $5^{\circ}$ valgus angulation, but none of them had any functional loss. One patient who had a tibia fracture on the same side as the femur fracture had $40^{\circ}$ knee flexion loss after Ilizarov external fixator treatment for tibia fracture. There was no deep infection, implant failure, nonunion, or limb length disparity in this group.

\section{DISCUSSION}

The aim of treatment of femoral fractures is normal bone alignment and length, early mobilization with gradually increasing weight bearing and normal knee and hip functional range of motion. ${ }^{[8-10]}$ The management of femur fractures has evolved significantly in recent years. Internal fixation based on anatomical reduction and rigid fixation of diaphyseal bone fragments is no longer the goal. Minimal surgical trauma and preservation of the blood supply of the bone and soft tissue are considered the most important factors in bone healing. 
Plate-screws fixation of comminuted fractures is advised by many authors. ${ }^{[21]}$ Papakostidis et al. ${ }^{[22]}$ reported that $81 \%$ of patients treated with plate and screw fixation had comminuted fractures. In our study, $75 \%$ of patients in Group I had comminuted fractures. Patients in Group II had more simple and stable fractures than in Group I.

There is no consensus regarding the timing of surgery for femoral fractures, and priority must be given to the life-threatening injuries. According to most authors, early surgery means fixation in the first 24 hours. ${ }^{[23]}$ However, if other system injury accompanies femur fracture, early surgery may cause pulmonary embolism, adult respiratory distress syndrome or multiple organ failure in hemodynamically unstable patients. ${ }^{[23]}$ Pape et al., ${ }^{[24]}$ Jaicks et al. ${ }^{[25]}$ and Townsend et al. ${ }^{[26]}$ reported that early fixation of femur fractures in patients with head and chest injury increases morbidity and mortality rates. However, findings of Carlson et al. ${ }^{[27]}$ and Bosse et al. ${ }^{[28]}$ do not support the other authors. In these reports, there was no increase in adult respiratory distress syndrome, pneumonia, pulmonary embolism, multiple organ failure, or death with early fixation in patients with thoracic injury. There was no such complication in our study.

In our study, average time to surgery was 5.4 days in Group I and 5.3 days in Group II. There was no statistical difference between the groups. We believe that fixation must be performed as soon as possible, but if there is an additional life- threatening injury, surgery must be delayed until hemodynamic stability is achieved.

In many reports, duration of operation and blood loss were lower with IMN fixation than with plate and screw fixation..$^{[2,29-33]}$ However, Vaidya et al. ${ }^{[34]}$ reported that plate-screw fixation resulted in shorter operation time and less blood loss. In our study, blood loss, duration of operation and fluoroscopy usage time were similar in both groups because both techniques were performed via small incisions, and fluoroscope was used only for fracture reduction.

Average hospital stay of patients treated with IMN was 19.8 days in Ertürer et al.' ${ }^{[30]}$ study and 19.5 days in Johnson et al.'s ${ }^{[35]}$ study. In Frankhauser et al.'s $\mathrm{s}^{[36]}$ study, average duration of hospitalization of patients treated with plate and screw fixation was 22 days. In our study, duration of hospitalization was 16.8 days for Group I and 14.2 days for Group II, and there was no statistical difference between them. Duration of hospitalization depends more on the presence of any additional systemic injury in patients and early complications rather than the treatment method itself.

Mean bone union time in our study was 4.6 months for Group I and 5 months for Group II. Both results are correlated with the literature. ${ }^{[8,37-39]}$ In both techniques, fractures were reduced indirectly without stripping the soft tissues. With biological fixation method, early callus formation and secondary fracture healing are the primary targets.

The nonunion rate of femur fracture treated with IMN was reported as between $0 \%$ and $7.6 \% .^{[7,8,40-43]}$ The nonunion rate of plate-screw fixation was reported as between $0 \%$ and $19 \%{ }^{[15,21,22,34,38,44]}$ In our study, there was no nonunion in Group II, but 2 nonunion cases were detected in Group I. The first patient had femoral neck fracture and patella fracture on the same side with wide soft tissue injury. The other patient was an open fracture with wound infection. Both patients were reoperated and implant revision and bone grafting were performed. Kinast et al. ${ }^{[45]}$ compared traditional anatomic reduction and biological fixation methods in subtrochanteric femur fractures. They found that there was no nonunion case with biological fixation method, but a $16.6 \%$ nonunion rate was detected using the traditional method. In a similar study of Siebenrock et al., ${ }^{[1]}$ the nonunion rate was $7 \%$ with biological method and $16 \%$ with traditional method. Farouk and Krettek ${ }^{[46]}$ conducted a study on fresh human cadavers and found that percutaneous minimal invasive plating technique disrupts the femoral blood supply less than the traditional open method.

Infection after femoral fracture fixation is a frequent complication. Infection rates were reported to be higher with plate and screw fixation than with IMN. ${ }^{[8,31,40,47]}$ In our study, there was no statistical difference between the two groups in terms of infection. We thought that closed reduction of the fracture, preservation of blood supply and intact periosteum could result in a lower contamination rate and less infection.

Papakostidis et al. ${ }^{[22]}$ reported a malunion rate of $0-29 \%$ for femur fractures treated with plate and screw biological fixation technique. They found that the cause of malunion was generally inadequate intraoperative reduction. According to Schütz et al., ${ }^{[48]}$ closed reduction of comminuted fractures may be difficult and this could be the cause of malunion. Malunion rates of fractures in our series were similar to those reported in the literature. ${ }^{[8,22,41,43,48]}$ We believe that the malunion rate correlates with inadequate intraoperative reduction rather than the selected fixation method of IMN or plate and screws. Proper intraoperative evaluation of limb alignment as described by Krettek et al. ${ }^{[20]}$ could decrease this complication.

Among the most important complications after long bone fractures are pulmonary complications. IMN was not advised in patients with chest trauma because of increased pulmonary embolism rate. ${ }^{[24]}$ Bosse et al. ${ }^{[28]}$ reported that there was no difference between 
plate-screws and IMN in terms of pulmonary complications. We did not detect any pulmonary complications in our patients.

Locked IMN can be used in all femur shaft fractures with a high union rate, low complication rate and sufficient functional results. However, biological internal fixation with plate and screws is an alternative technique to locked IMN in patients with multi-trauma or compromised pulmonary or cardiac function, or in complex comminuted or segmented diaphyseal or metaphyseal fractures.

\section{REFERENCES}

1. Bucholz RW, Brumback RJ. Fractures of shaft of the femur. In: Rockwood CA, Gren DP, Bucholz RW, Heckman JD, editors. Fractures in adults. Vol.2, 4th ed. New York: LippincottRaven; 1996. p. 1827-918.

2. Whittle AP, George W, Wood II. Fractures of lower extremity. In: Canale ST, editor. Campbell's operative orthopaedics. Vol. 3, 10th ed. St. Louis: Mosby; 2003. p. 2725-872.

3. Muller ME, Allgower M, Schineider $\mathrm{R}$, Willeneger $\mathrm{H}$. Mannual of internal fixation. 2nd ed. Heidelberg, German: Springer-Verlag; 1979.

4. Bucholz RW, Jones A. Fractures of the shaft of the femur. J Bone Joint Surg [Am] 1991;73:1561-6.

5. Gerber C, Mast JW, Ganz R. Biological internal fixation of fractures. Arch Orthop Trauma Surg 1990;109:295-303.

6. Leunig M, Hertel R, Siebenrock KA, Ballmer FT, Mast JW, Ganz R. The evolution of indirect reduction techniques for the treatment of fractures. Clin Orthop Relat Res 2000:7-14.

7. Christie J, Court-Brown C, Kinninmonth AW, Howie CR. Intramedullary locking nails in the management of femoral shaft fractures. J Bone Joint Surg Br 1988;70:206-10.

8. Kempf I, Grosse A, Beck G. Closed locked intramedullary nailing. Its application to comminuted fractures of the femur. J Bone Joint Surg [Am] 1985;67:709-20.

9. Thoresen BO, Alho A, Ekeland A, Strømsøe K, Follerås G, Haukebø A. Interlocking intramedullary nailing in femoral shaft fractures. A report of forty-eight cases. J Bone Joint Surg [Am] 1985;67:1313-20.

10. Winquist RA, Hansen ST Jr, Clawson DK. Closed intramedullary nailing of femoral fractures. A report of five hundred and twenty cases. J Bone Joint Surg [Am] 1984;66:529-39.

11. Perren SM. Evolution of the internal fixation of long bone fractures. The scientific basis of biological internal fixation: choosing a new balance between stability and biology. J Bone Joint Surg [Br] 2002;84:1093-110.

12. Baumgaertel F, Buhl M, Rahn BA. Fracture healing in biological plate osteosynthesis. Injury 1998;29 Suppl 3:C3-6.

13. Perren SM, Ganz R. Biological internal fixation of fractures: the balance between biology and mechanics. European Instr Course Lect 1997;3:161-3.

14. Muratlı HH, Can M, Biçimoğlu A. Kırık tespitinde güncel yaklaşım: İnternal atelleme. TOTBİD Dergisi 2003;2:44-51.

15. Rozbruch SR, Muller U, Gautier E, Ganz R. The evaluation of femoral shaft plating technique. Clin Orthop Relat Res 1998;354:195-208.

16. Perren SM. Physical and biological aspects of fracture healing with special reference to internal fixation. Clin Orthop Relat Res 1979:175-96.

17. McKibbin B. The biology of fracture healing in long bones. J
Bone Joint Surg [Br] 1978;60-B:150-62.

18. Muller ME, Nazarian S, Koch P, Schatzker J, (editors). The comprehensive classification of fractures of long bones. Berlin: Springer; 1990. p. 120-1

19. Gustilo RB, Anderson JT. Prevention of infection in the treatment of one thousand and twenty-five open fractures of long bones: retrospective and prospective analyses. J Bone Joint Surg [Am] 1976;58:453-8.

20. Krettek C, Miclau T, Grün O, Schandelmaier P, Tscherne H. Intraoperative control of axes, rotation and length in femoral and tibial fractures. Technical note. Injury 1998;29:C29-39.

21. Biçimoğlu A, Muratli HH, Yağmurlu MF, Tabak AY, Aktekin $\mathrm{CN}$. The results of plate fixation with the use of biological fixation principles and minimally invasive technique in femur fractures. Acta Orthop Traumatol Turc 2002;36:129-35.

22. Papakostidis C, Grotz MR, Papadokostakis G, Dimitriou R, Giannoudis PV. Femoral biologic plate fixation. Clin Orthop Relat Res 2006;450:193-202.

23. Brundage SI, McGhan R, Jurkovich GJ, Mack CD, Maier RV. Timing of femur fracture fixation: effect on outcome in patients with thoracic and head injuries. J Trauma 2002;52:299307.

24. Pape HC, Auf'm'Kolk M, Paffrath T, Regel G, Sturm JA, Tscherne H. Primary intramedullary femur fixation in multiple trauma patients with associated lung contusion-a cause of posttraumatic ARDS? J Trauma 1993;34:540-8.

25. Jaicks RR, Cohn SM, Moller BA. Early fracture fixation may be deleterious after head injury. J Trauma 1997;42:1-6.

26. Townsend RN, Lheureau T, Protech J, Riemer B, Simon D. Timing fracture repair in patients with severe brain injury (Glasgow Coma Scale score <9) J Trauma 1998;44:977-83.

27. Carlson DW, Rodman GH Jr, Kaehr D, Hage J, Misinski M. Femur fractures in chest-injured patients: is reaming contraindicated? J Orthop Trauma 1998;12:164-8.

28. Bosse MJ, MacKenzie EJ, Riemer BL, Brumback RJ, McCarthy ML, Burgess AR, et al. Adult respiratory distress syndrome, pneumonia, and mortality following thoracic injury and a femoral fracture treated either with intramedullary nailing with reaming or with a plate. A comparative study. J Bone Joint Surg [Am] 1997;79:799-809.

29. Arpacioğlu MO, Akmaz I, Mahiroğullari M, Kiral A, Rodop O. Treatment of femoral shaft fractures by interlocking intramedullary nailing in adults. Acta Orthop Traumatol Turc 2003;37:203-12.

30. Ertürer E, Öztürk İ, Dirik Y, Uzun M, Aksoy B. Erişkinlerdeki femur cisim kırıklarında kilitli oymasız intramedüller çivi osteosentezinin radyografik ve fonksiyonel sonuçları. Acta Orthop Traumatol Turc 2005;39;381-6.

31. Siebenrock KA, Müller U, Ganz R. Indirect reduction with a condylar blade plate for osteosynthesis of subtrochanteric femoral fractures. Injury 1998;29:C7-15.

32. Krettek C, Schandelmaier P, Miclau T, Tscherne H. Minimally invasive percutaneous plate osteosynthesis (MIPPO) using the DCS in proximal and distal femoral fractures. Injury 1997;28:A20-30.

33. Nungu KS, Olerud C, Rehnberg L. Treatment of subtrochanteric fractures with the AO dynamic condylar screw. Injury 1993;24:90-2.

34. Vaidya SV, Dholakia DB, Chatterjee A. The use of a dynamic condylar screw and biological reduction techniques for subtrochanteric femur fracture. Injury 2003;34:123-8.

35. Johnson KD, Johnston DW, Parker B. Comminuted femoralshaft fractures: treatment by roller traction, cerclage wires and an intramedullary nail, or an interlocking intramedullary 
nail. J Bone Joint Surg [Am] 1984;66:1222-35.

36. Fankhauser F, Gruber G, Schippinger G, Boldin C, Hofer $\mathrm{HP}$, Grechenig W, et al. Minimal-invasive treatment of distal femoral fractures with the LISS (Less Invasive Stabilization System): a prospective study of 30 fractures with a follow up of 20 months. Acta Orthop Scand 2004;75:56-60.

37. Tüzüner T, Subaşi M, Kapukaya A, Necmioğlu NS. Treatment of femoral shaft fractures with interlocking intramedullary nailing. Acta Orthop Traumatol Turc 2002;36:211-9.

38. Kesemenli C, Subasi M, Necmioglu S, Kapukaya A. Treatment of multifragmentary fractures of the femur by indirect reduction (biological) and plate fixation. Injury 2002;33:6919.

39. Heitemeyer U, Kemper F, Hierholzer G, Haines J. Severely comminuted femoral shaft fractures: treatment by bridging-plate osteosynthesis. Arch Orthop Trauma Surg 1987;106:327-30.

40. Ürgüden M, Özdemir H, Yanat AN, İnanmaz E, Akyıldız FF, Altınel E. Femur kırıklarının kilitli intramedüller çivi ile tedavisinde karşılaşılan sorunlar. Acta Orthop Traumatol Turc 2001;35:418-29.

41. Søjbjerg JO, Eiskjaer S, Møller-Larsen F. Locked nailing of comminuted and unstable fractures of the femur. J Bone Joint Surg [Br] 1990;72:23-5.
42. Klemm KW, Börner M. Interlocking nailing of complex fractures of the femur and tibia. Clin Orthop Relat Res 1986:89100 .

43. Wiss DA, Fleming CH, Matta JM, Clark D. Comminuted and rotationally unstable fractures of the femur treated with an interlocking nail. Clin Orthop Relat Res 1986:35-47.

44. Huang HT, Huang PJ, Su JY, Lin SY. Indirect reduction and bridge plating of supracondylar fractures of the femur. Injury 2003;34:135-40.

45. Kinast C, Bolhofner BR, Mast JW, Ganz R. Subtrochanteric fractures of the femur. Results of treatment with the 95 degrees condylar blade-plate. Clin Orthop Relat Res 1989:122-30.

46. Farouk O, Krettek C, Miclau T, Schandelmaier P, Guy P, Tscherne H. Minimally invasive plate osteosynthesis: does percutaneous plating disrupt femoral blood supply less than the traditional technique? J Orthop Trauma 1999;13:401-6.

47. McKee MD, Waddell JP. Intramedullary nailing of femoral fractures in morbidly obese patients. J Trauma 1994;36:20810 .

48. Schütz M, Müller M, Krettek C, Höntzsch D, Regazzoni P, Ganz R, et al. Minimally invasive fracture stabilization of distal femoral fractures with the LISS: a prospective multicenter study. Results of a clinical study with special emphasis on difficult cases. Injury 2001;32:48-54. 